\title{
INTELLECTUAL PROPERTY IN A PERIPHERAL JURISDICTION: A MATTER OF POLICY?
}

\author{
Hector L MacQueen* \\ in Vaver, D avid, and Bently, Lionel (eds) (eds) Intellectual Property in the $\mathrm{N}$ ew Millennium \\ (Cambridge University Press, 2004) pp.58-76
}

The law [of intellectual property] ... is largely based on statutes applicable to the United Kingdom as a whole. By contrast, most of the case law has been decided in English courts. Nonetheless there are three separate jurisdictions to which litigants may on occasion resort. While the procedures and remedies available in Northern Ireland closely resemble those of England and Wales, the Scottish system is often distinct in substance or in nomenclature. The special characteristics of Scottish litigation, however, are not pursued here. ${ }^{1}$

Bill Cornish has not often had other occasion to refer to Scots law or Scotland in the course of his published work, whether on intellectual property, ${ }^{2}$ legal history, ${ }^{3}$ or other topics. ${ }^{4}$ But nevertheless his support of colleagues working on intellectual property in Scotland, notably with regard to the AHRB Research Centre for Intellectual Property and Technology Law at the Edinburgh Law School, has been generous, unstinting and greatly appreciated by the beneficiaries.

The thought that the topic for this essay could be appropiately addressed in Bill's honour was prompted by recollection of some gently amused comments of his at the time about the opening ceremonies of the Scottish Parliament on 1 July 1999, in particular his musician's appreciation of the singing in the chamber (and, significantly, before the Queen) of Burns' 'A man's a man for a' that'. ${ }^{5}$ On the face

\footnotetext{
* I am grateful to Frances MacQueen, Alan Peacock, Donald Smith and Charlotte Waelde for helpful discussions of some of the issues raised in this paper. I have also benefited from my time as a member of the following groups: the board of directors of the Edinburgh University technology transfer company, Edinburgh Research and Innovation Ltd; the British Academy working party on the contributions of the arts, humanities and social sciences; and the DTI Intellectual Property Advisory Committee. All website references were last checked on 31 December 2003.

${ }^{1} \mathrm{~W}$ R Cornish and D Llewelyn, Intellectual property: patents, copyright, trade marks and allied rights, 5th edition, (London: Sweet and Maxwell, 2003, ch. 1-03. A similar paragraph is found in all the preceding editions of the book, which are of course by Bill Cornish alone.

${ }^{2}$ Note however recognition of the significance of the Scottish dimension in the early history of copyright in W R Cornish, “The author's surrogate: the genesis of British copyright”, in K O'Donovan and G R Rubin, Human rights and legal history: essays in honour of Brian Simpson (Oxford: Oxford University Press, 2000), 254-70, at 259-60. To the references there given, add now A Mann, "Scottish copyright before the statute of 1710", 2000 Juridical Review 11, and idem, The Scottish book trade 1500-1720: print, commerce and print control in early modern Scotland (East Linton: Tuckwell Press, 2000), ch. 4.

${ }^{3}$ But see W R Cornish \& G de N Clark, Law and society in England 1750-1950 (London: Sweet \& Maxwell, 1989), at 18, 63, 277.

${ }^{4}$ See e.g. W R Cornish, The jury (London: Pelican, 1971), at 16, 282-3. Note also the impact of Bill's work on restitution (Scotticé, unjustified enrichment) - see his “'Colour of office': restitutionary redress against public authority" [The Sultan Azlan Shah Law Lecture 1986], (1987) Journal of Malaysian and Comparative Law 41 - on the House of Lords in Woolwich Building Society v Inland Revenue [1993] AC 70, a case which was of crucial importance to the re-orientation of Scots enrichment law in Morgan Guaranty Co of New York v Lothian Regional Council 1995 SC 151. ${ }^{5}$ For the programme of songs and readings at the opening of the Scottish Parliament, see http://news.bbc.co.uk/1/hi/special_report/1999/06/99/scottish_parliament_opening/377516.stm.
} 
of it, however, Scottish devolution did not seem a matter of much moment for intellectual property lawyers as such. The Scotland Act 1998 reserves to the Westminster Parliament legislative competence over intellectual property (henceforth 'IP'), Internet services, electronic encryption and, indeed, much commercial law in general. ${ }^{6}$ And even if the devolution settlement is not necessarily set in stone for ever, it seems unlikely that there will ever be a legislative power to create Scottish systems of patents, copyright, trade marks, designs, and so on; indeed, the initiative on these subjects now does not even lie at UK, but rather at European and global levels.

Despite all this, on 22 June 1999, I found myself arguing in the annual lecture of the Scottish Group of the Society for Computers and Law that IP was an important subject for a devolved Scotland. ${ }^{7}$ I pointed out that in modern development and reform of IP laws the most vocal and powerful influences came from large industry and others in the 'centres' of IP, while those from the 'periphery', such as Scotland, were scarcely to be heard at all, even although their interests were not necessarily coterminous with those at the centre. The fact that the Scottish Parliament could not legislate in a particular area did not mean that its members (or the Scottish Executive) could not talk about that subject. I wrote as follows:

We do not know what Scottish business wants or needs from intellectual property law as its growth and development continues. We need to ask ourselves whether there is any connection between Scotland's apparent underperformance in entrepreneurship and starting up businesses, and failures either of intellectual property itself or in the knowledge of those who might benefit from it. ... It is with this sort of thing, I think, that an intellectual property research centre based in Scotland can play a useful role. ... [W] can also try to find out more about intellectual property in Scotland, and represent to the principal centres of the subject what is important on the periphery. ... I would hope that, whatever may be the formal constraints on the legislative competence of the Scottish Parliament, it will feel free to discuss intellectual property as an important element in the economic performance of this country, but will wish to do so on the basis of research and knowledge. ${ }^{8}$

Five years later, with the Scottish Parliament and Executive firmly established and fully operational, the time seems ripe for a return to these issues.

In the 1999 lecture I observed that the Patent Office published no breakdown of the parts of the United Kingdom from which applications for registered IP rights (henceforth 'IPR') came. This has ceased to be the case since the Office's Annual Report for 2001, when it began to provide just such a regional analysis of applications for and grants of rights. The 'regions' used for this purpose are aligned with the geographical areas covered by the regional development agencies (in Scotland,

\footnotetext{
An opportunity for some reciprocal amusement arose from the proceedings on 2 May 2001 when Nelson Mandela became an Honorary Fellow of Magdalene College, Cambridge, of which Bill was then President: see the BBC's report at http://news.bbc.co.uk/1/hi/uk/1309216.stm.

${ }^{6}$ Scotland Act 1998, Schedule 5 Head C.

${ }^{7}$ The lecture is published as "Intellectual property in a peripheral jurisdiction", (1999) 10(4)

Computers and Law 30.

${ }^{8}$ Ibid, 34-5.
} 
principally Scottish Enterprise). The figures for Scotland which can so far be derived from this exercise are given in Table 1.

Table 1: Filings for and grants of registered intellectual property rights from Scotland 1999-2002.

Bracketed percentage figures relate the Scottish to the overall UK numbers.

\begin{tabular}{|c|c|c|c|c|}
\hline & 1999 & 2000 & 2001 & 2002 \\
\hline Patent applications filed & $\mathrm{n} / \mathrm{a}$ & $\begin{array}{c}1,198 \\
(5.55 \%)\end{array}$ & $\begin{array}{c}1,120 \\
(5.35 \%)\end{array}$ & $\begin{array}{c}1,165 \\
(5.77 \%)\end{array}$ \\
\hline Patent applications granted & $\mathrm{n} / \mathrm{a}$ & $\begin{array}{c}141 \\
(4.76 \%)\end{array}$ & $\begin{array}{c}107 \\
(3.84 \%)\end{array}$ & $\begin{array}{c}163 \\
(4.92 \%) \\
\end{array}$ \\
\hline Trade mark applications filed & $\begin{array}{c}1,056 \\
(4.79 \%)\end{array}$ & $\begin{array}{c}1,174 \\
(4.61 \%)\end{array}$ & $\begin{array}{c}1,044 \\
(5.01 \%)\end{array}$ & $\begin{array}{c}1,164 \\
(5.37 \%)\end{array}$ \\
\hline $\begin{array}{l}\text { Trade mark applications } \\
\text { registered }\end{array}$ & $\begin{array}{c}787 \\
(4.98 \%)\end{array}$ & $\begin{array}{c}889 \\
(4.61 \%) \\
\end{array}$ & $\begin{array}{c}772 \\
(4.10 \%)\end{array}$ & $\begin{array}{c}891 \\
(5.05 \%)\end{array}$ \\
\hline Design applications filed & $\begin{array}{c}228 \\
(5.88 \%)\end{array}$ & $\begin{array}{c}152 \\
(4.09 \%)\end{array}$ & $\begin{array}{c}141 \\
(4.01 \%)\end{array}$ & $\begin{array}{c}218 \\
(4.45 \%)\end{array}$ \\
\hline Design applications registered & $\begin{array}{c}217 \\
(5.43 \%)\end{array}$ & $\begin{array}{c}209 \\
(5.07 \%)\end{array}$ & $\begin{array}{c}177 \\
(4.56 \%)\end{array}$ & $\begin{array}{c}186 \\
(4.38 \%)\end{array}$ \\
\hline
\end{tabular}

Source: Patent Office Annual Reports 2001-2003.

As well as gaining a better-informed perspective on the significance of the registered IPR in Scotland, one might deduce from the figures in Table 1 that overall the country has recently been contributing between 4 and 5 per cent of the United Kingdom's registered IPR. This also appears to match Scotland's contribution to overall research and development (R\&D) expenditure in the UK, ${ }^{9}$ both figures representing an under-contribution in relation to Scotland's 8.6 per cent share of the UK population. The numbers of IP registrations have also been in decline relative to the rest of the United Kingdom, apart from a very modest recovery in 2002. The overall UK performance in that period saw a slight falling off in application and grant rates, apart from a peaking of trade mark applications and grants in 2000 and a small recovery in 2002. In terms of numbers of filings and grants, Scotland out-performs consistently only Wales and Northern Ireland amongst the other regions of the United Kingdom. ${ }^{10}$ In 2000, however, there were more patent applications from Scotland than from the East Midlands (1,198 to 990), although the English region gained more

\footnotetext{
${ }^{9}$ Scottish Economic Statistics 2003, table 2.12 (at http://www.scotland.gov.uk/stats/ses2003/ses0317.asp).

${ }^{10}$ The English regions listed in the Patent Office reports are North East, North West, East Midlands, West Midlands, South West, London, South East, East of England. As noted below, Yorkshire was introduced to the patent table in the 2002 report. As might be expected, London, South East and East of England are the 'hot spots' for filing and granting registered intellectual property rights.
} 
patent grants, with 153 to 141. In 2001 Scotland (1,120 filings and 107 grants) was ahead of the North East (440 filings and 46 grants) on patents; but the North East's apparently catastrophic decline from 2000 levels of 1,632 filings and 208 grants was to be explained by the creation of a new entry in the 2001 table, for that large northeastern county, Yorkshire, which by itself managed to out-perform Scotland that year, with 1,299 filings and 143 grants. Yorkshire remained ahead of Scotland in 2002, with 1,240 filings and 177 grants.

In its 2003 report, Measuring Scotland's progress towards a smart, successful Scotland, ${ }^{11}$ the Fraser of Allander Institute from Strathclyde University noted that the Scottish patenting rate was generally lagging in the United Kingdom, even in relation to those parts of England with a generally similar economic structure, but suggested that the particularly wide gap between Scotland and the south-east of England ${ }^{12}$ 'probably reflects the location of headquarters and corporate R\&D departments'. ${ }^{3}$ Overall, however, the low patenting rate 'may also indicate that Scotland is failing to capitalise fully on converting knowledge into successful products and processes'. 14

The Fraser of Allander report is part of the Scottish Executive's regular assessment of Scotland's economic performance, which has followed since the publication in June 2000 of the Executive's The Way Forward: Framework for Economic Development in Scotland. ${ }^{15}$ This identified strengths in sectors such as electrical and instrument engineering, whisky, tourism and the North Sea, and in basic scientific research; these were offset, however, by weaknesses, judged against both international (OECD) and UK standards; in particular, low productivity, corporate $\mathrm{R} \& \mathrm{D}$, innovation, and business birth rate, and the lack of enterprise headquarters and global businesses. Priorities for action included an approach to enterprise support through the Executive's economic development agencies ${ }^{16}$ that would encourage an enterprise culture, support innovation and the commercialisation of research by business and industry, assist new business formation, and foster tourism. The Executive also promised to develop knowledge of economic performance in Scotland, the better to assist the formation of, in what has become a well-worn phrase, evidence-based policy. ${ }^{17}$

In January 2001 the then Minister for Enterprise and Lifelong Learning, Wendy Alexander, published a document entitled A Smart, Successful Scotland, ${ }^{18}$ which set out a comprehensive policy statement of what the Executive wanted from its enterprise agencies and networks. This signalled a shift from a basic policy of encouraging inward investment by foreign firms to one of internal technology transfer and better exploitation of the local research base. In particular the importance of 'clusters' - the interaction and collaboration of industry and the universities in particular localities - was highlighted, with biotechnology said to provide a key

\footnotetext{
${ }^{11}$ Accessible at http://www.scotland.gov.uk/library5/government/sss03-00.asp.

12 'South-east' here means the London, South East and East of England regions taken altogether.

${ }^{13}$ Fraser of Allander Institute Report (above note 11), at 23.

14 Ibid.

${ }^{15}$ SE/2000/58 (at http://www.scotland.gov.uk/library3/economics/feds-00.asp). The Framework is now under review: see http://www.scotland.gov.uk/pages/news/2003/11/SEel147.aspx (6 November 2003).

${ }^{16}$ Scottish Enterprise and Highlands and Islands Enterprise (HIE), under which there are networks of local enterprise companies (LECs).

${ }^{17}$ Sometimes modified to the cannier evidence-influenced, or evidence-informed, policy.

${ }^{18}$ Accessible at http://www.scotland.gov.uk/library3/enterprise/smart-successful-scotland.pdf.
} 
instance already in existence. Under the heading 'Increased commercialisation of research and innovation', the document stressed the need to increase levels of R\&D spending in Scottish companies, which lagged well behind the UK average; to create more effective technology transfer between universities and businesses; and to increase the number of patent registrations from Scotland. The weaknesses of low business start-up rates and poor commercial and industrial R\&D investment were thus to be addressed by better use of the research strengths of the Scottish universities and other research institutions. ${ }^{19}$

The policy required the business sector to recognise and pursue the value of research in innovation and development, while also getting the university and research worlds to involve themselves much more in the commercial exploitation of the ideas which they generated. ${ }^{20}$ IPRs, and in particular patents, were to be an important element in this mix. Also of significance were the 'spin-out' and 'start-up' companies through which university research was already being commercialised; 'spin-outs' being the enterprises in which the relevant university retained at least a share of ownership, and 'start-ups' those in which university staff and students were permitted to take their research to the marketplace without significant university involvement.

The Scottish universities themselves were already well aware of the importance of the IP generated within their laboratories and elsewhere, although perhaps more for their own than the nation's economic benefit. In 1997 the Scottish Committee of the Dearing National Inquiry into Higher Education endorsed the view that 'revenues generated by the exploitation of intellectual property could provide a substantial additional source of income to [higher education] institutions. ${ }^{21}$ In a document published in May 2002 Universities UK claimed that 'Scottish universities now own more intellectual property than Scottish industry', ${ }^{22}$ while the Universities Scotland website states that 35 per cent of the royalties earned by UK universities from IP comes to Scottish universities. ${ }^{23}$ In 2000-2001 Scottish universities filed around 10 per cent of all patent applications from Scotland, proportionately more than double the figure for university patent applications across the whole United Kingdom. ${ }^{24}$ The Higher Education Business Interaction Survey for the academic year 2000-2001 showed that 'Scotland's higher education institutions have been and are generally more active than the rest of the UK regarding commercialisation of their IP, contributing: 11 per cent of new university patents filed, 15 per cent of UK licences

\footnotetext{
${ }^{19}$ Significantly, from the beginning of devolution the universities were placed under the aegis of the Enterprise and Lifelong Learning rather than the Education Department of the Scottish Executive.

${ }^{20}$ This is of course part of a world-wide trend. See Ann Monotti with Sam Ricketson, Universities and intellectual property: ownership and exploitation (Oxford: Oxford University Press, 2003). For critical discussions of its significance for the 'mission' of research universities from a USA perspective, see Corynne McSherry, Who owns academic work? Battling for control of intellectual property (Cambridge, Mass., and London: Harvard University Press, 2001), and Derek Bok, Universities in the marketplace: the commercialisation of higher education (Princeton, N.J.: Princeton University Press, 2003).

${ }_{21}^{21}$ para. 4.113 (accessible at http://www.leeds.ac.uk/educol/ncihe/scottish.htm).

${ }^{22}$ Universities UK, The University culture of enterprise: knowledge transfer across the nation (May 2002), 22 (at http://www.universitiesuk.ac.uk/bookshop/downloads/knowledgetransfer.pdf).

${ }^{23}$ See the Universities Scotland website: http://www.universities-scotland.ac.uk/Facts\%20and\%20Figures/Research.pdf (at 2).

${ }^{24}$ Higher education business interaction survey 2000-01, Higher Education Funding Council for England \& Wales 2003, and Patent Office, Annual facts and figures 2000-2001, Patent Office 2001.
} 
granted and 14 per cent of spin-off companies formed in 2000/2001'.25 In that year 62 university spin-offs and start-ups commenced operations, employing 931 people; while 59 such companies started within the past three years were still in business. ${ }^{26}$

The key change in the 'smart, successful Scotland' policy, however, was that the IP produced by the university and research sectors was to be deployed, not as an additional source of revenue to support the efforts of the sector as such, but as a means to develop economic activity across Scotland as a whole. The main response of Scottish Enterprise to this policy has been the establishment of three Intermediary Technology Institutes (ITIs), the creation of which was announced in December 2002 and which have since been slowly coming into full operation. ${ }^{27}$ There are ITIs for Life Sciences, Energy, and Communications Technology and Digital Media (Techmedia), located respectively in Dundee, Aberdeen and Glasgow. The idea is that the ITIs will be 'hubs', each identifying, commissioning, and supporting the diffusion of market-focused, but pre-competitive, research in its field. They will thus, it is hoped, be in a position to help solve the problems of the lack of commercial $\mathrm{R} \& \mathrm{D}$, and the difficulty of putting industry and commerce in touch with relevant university research. ${ }^{28}$

However, IPRs present some difficulties for the ITIs. Thus when Gordon Campbell, the chair of ITI Scotland, and Dr Janet Brown, the director of competitive business for Scottish Enterprise, jointly gave evidence about the ITIs to the Enterprise and Culture Committee of the Scottish Parliament on 25 November 2003, they explained that the institutes will be essentially commissioning bodies whose remit is to identify market opportunities and to match research to those opportunities; that is to say, to provide a link between the basic research in the universities and the further applied research needed to transfer that work to a market. The ITIs, it appeared, would wish to be purchasers of IP from the universities, rather than licensees. Campbell said: 'Our preferred solution is for the intellectual property to reside with the institutes, so that the institutes can have the maximum flexibility in helping the commercialisation of the intellectual property. ${ }^{29}$ One can see that universities valuing their IP might have some doubts about this position, which no doubt explains Campbell's additional observation that the approach 'is not cast in stone. We are in

\footnotetext{
${ }^{25}$ Higher education business interaction survey 2000-01, Scottish Report, introduction, para. 11 (accessed via the Scottish Executive website, at http://www.scotland.gov.uk/about/ELLD/EI/00016585/HEBI_Scot_2001.pdf). The UK university commercialisation survey financial year 2002 published in November 2003 by Nottingham University Business School, the Association for University Research and Industry Links and the University Companies Association, which reports a general increase of activity and an out-performance of US and Canadian universities in technology transfer in terms of return on money spent, cannot be broken down to provide Scottish figures more up-to-date than those in the text. The report is accessible at http://www.auril.org.uk/webpages/UKTT_NUBS_FY2002_FR.pdf.

${ }^{26}$ Scottish Report (above, note 25), paras. 7.2, 7.3.

${ }^{27}$ See generally Scottish Enterprise, ITI Scotland: realising Scotland's potential (December 2002), accessible at http://www.scottish-enterprise.com/publications/iti_scotland_-_realising_scotlands_potential.pdf; and the ITIs' website, http://www.itiscotland.com/.

${ }^{28}$ Note also the existence of a website, http://www.scottishresearch.com, listing Scottish university inventions, set up by the Scottish Higher Education Funding Council and Scottish Enterprise.

${ }^{29}$ Scottish Parliament Official Report, 25 November 2003, col. 310. The Official Report can be accessed at the Scottish Parliament website, http://www.scottish.parliament.uk/.
} 
discussions with the universities and their representatives about how that intellectual property will be maintained. ${ }^{, 30}$

There were also some signs of tension between Mr Campbell and Dr Brown about IP. Thus Mr Campbell observed: 'We see intellectual property as being a source of income to the institutes, so that they can reinvest in further development. There are a number of ways in which income for the institutes can be generated and a number of ways in which intellectual property can be used to the benefit of Scotland, from licensing the intellectual property to companies to companies developing products based on intellectual property, which may or may not be as a result of licensing. ${ }^{31}$ Dr Brown then immediately pointed out that 'the measurement framework that Scottish Enterprise will apply will aim not to maximise the return of intellectual property revenue to the ITIs, but to maximise company value. It is not about selling to the highest bidder, but about selling to gain the best economic impact for Scotland.' ${ }^{32}$ The position of the universities providing the initial IP was left unexplained, although Dr Brown later indicated that ITIs are not merely about commercialising existing university research or basic science, but rather more about 'allowing an additional amount of research to be undertaken ... to pull all those pieces of research together so that a company can use the research'. ${ }^{3}$

The debate about IP ownership and commercialisation is also evident in another guise in the Lambert Review of Business-University Collaboration published in December 2003. ${ }^{34}$ Although this report was commissioned by the Treasury, it relates to the devolved areas of higher education and economic development agencies, and it is, as the report acknowledges, 'for the devolved administrations to consult on and decide how to take forward' its recommendations in their territories. Of especial relevance to the ITIs, and indeed to the Scottish higher education institutions, will be Lambert's view that the starting point for negotiations on research collaboration involving the universities should be the universities' ownership of the resulting IP unless industry had made a 'significant contribution' to the research, whereupon ownership should become negotiable. Lambert also suggests that university-industry research collaborations might be easier to agree if there could be voluntarily developed model contracts covering the ownership and exploitation of IP. Lack of clarity over ownership of IP in research collaborations makes for long and expensive negotiations, and it may be, suggests Lambert, that universities are setting too high a price in negotiations over IP. It needs to be remembered that public funding for the basic research carried out in universities is intended to benefit the economy as a whole rather than to create significant new sources of revenue for universities. ${ }^{35}$ In any

\footnotetext{
${ }^{30}$ Ibid, col. 310 .

${ }^{31}$ Bid, col. 311 .

32 Ibid, col. 311.

${ }^{33}$ Ibid, col. 325. The model thus seems to be Project Alba, for which see my SSCL lecture (above note

7) at 30. For the Enterprise and Culture Committee's rather anodyne response to what it had been told about ITIs, see its Third Report, 2003, Report on Scottish Solutions Inquiry (SP Paper 67, 18 December 2003), paras. 113, 114.

${ }^{34}$ Accessible at http://www.lambertreview.org.uk. The review was conducted by Richard Lambert.

${ }^{35}$ One might add, however, that, if so, it is not clear that publicly funded research should lead instead to the private profit of commercial enterprises.
} 
event, the US experience suggests that technology transfer activity produces for universities at most only relatively small amounts of money. ${ }^{36}$

A final relevant development regarding IP in devolved Scotland is the announcement on 3 December 2003 of a National Intellectual Assets Centre (NIAC), set up by the Scottish development agencies with funding from the Scottish Executive. ${ }^{37}$ The Centre will help Scottish firms protect and exploit, not only IP such as patents and trade marks, but also brands, employee know-how, trade secrets and technical information. It will promote awareness and provide advice on identification, protection and exploitation. The difference from the ITIs is that the NIAC will seek to help businesses with the 'intellectual assets' which they already have, rather than introducing them to producers of IP by research for material to take to market.

All this makes evident the basic point that the Scottish Executive has recognised IP as of fundamental importance for the development and improvement of economic performance in Scotland. In consequence, the subject has also been talked about many times in the Scottish Parliament. The evidence given before the Parliament's Enterprise and Culture Committee in November 2003 has already been discussed. In a number of earlier debates going back to at latest 2001, there were discussions of the issue of commercialisation of university research, a topic which also became embroiled in questions about the evaluation of university research and the future of the Research Assessment Exercise as well as the funding of universities more generally. ${ }^{38}$ The last is a particularly sensitive issue in Scotland, since one of the first acts of the Parliament by which there emerged a Scottish approach distinct from the rest of the United Kingdom was the abolition of 'up-front' university tuition fees in 2000. ${ }^{39}$ The emergence in 2003 of proposals for differential 'top-up' tuition fees to generate more funding for universities in England and Wales has thus led to considerable and, to date, inconclusive debate about the future funding of Scottish universities, especially given the generally agreed significance of their research to economic development. ${ }^{40}$

What evaluation may be made of the public discussion so far of IP in a devolved Scotland? The first point is that the discussion has focused almost entirely on policy issues and on the role of IP in economic development. Innovation, supported and made profitable by IPRs, is seen as the key to economic progress, rather than imitation, the antithesis of IP. There has been, however, little or no discussion of the substance of IP law, and of whether as it stands the law meets the

\footnotetext{
${ }^{36}$ See also Times Higher Education Supplement, 14 November 2003 ('Do not bank on spin-off income').

${ }^{37}$ See press release at http://www.scotland.gov.uk/pages/news/2003/12/SEEL198.aspx.

${ }^{38}$ See e.g. Scottish Parliament Official Report, 1 November 2001 (debate on teaching and research funding: future of Scottish Higher Education Funding Council); 6 November 2002 (debate on science and the Parliament); see also debates of Enterprise and Lifelong Learning Committee 8, 30 May, 12 June 2001.

${ }^{39}$ See the Education (Graduate Endowment and Student Support) (Scotland) Act 2001 (asp 6), partially implementing the 1999 Report of the (Cubie) Committee of Inquiry into Student Finance.

${ }^{40}$ By coincidence the Scottish Executive was conducting a Higher Education Review at the time 'topup' fees became a subject of public debate: see

http://www.scotland.gov.uk/about/ELLD/HESP/00016640/HEReview.aspx. See also the report of the Parliament's Enterprise and Culture Committee, cited above, note 33.
} 
perceived needs of either policy, university and other researchers, business or other potential users of the end products of research. Indeed, IP, when it is not taken to mean rather generally the knowledge which is held or developed by researchers, is often simply equiparated with patents, other forms of IP being ignored or treated as of relative unimportance or low priority. Yet new trade mark registrations can also be indications of new businesses starting up, or of existing businesses diversifying in a way which they believe to need a distinct identity in the marketplace, ${ }^{41}$ while design registrations likewise signal products which in themselves may not be new ideas but which will nonetheless be different from their competitors, wherever these may be.

The focus on patents can also be linked with a belief that economic development is to be achieved through 'high' rather than 'low tech' and traditional industries. While Scotland has strengths in high tech, the others identified by the Executive back in 2000 included ones - whisky and tourism, for example - to which forms of IP other than patents are highly relevant. But there has been nothing like the public discussion of this aspect to compare with what we have seen in relation to the commercialisation of university research.

Two examples must suffice to demonstrate why that wider discussion should be taking place. In the autumn of 2003 the highly traditional world of Scotch whisky was divided over the actions of the distillers Diageo in relation to its Cardhu brand of malt whisky. Because the brand was selling too well in a number of foreign markets, Diageo was running out of Cardhu single malt, ${ }^{42}$ and began to market, under its established labelling but as 'pure malt' Cardhu, a drink which was in fact a mixture of Speyside malts. ${ }^{43}$ This led to severe criticism from other distillers of malt whiskies, who saw in Diageo's actions the beginning of a process by which the distinctiveness of the concept of a 'single malt' whisky would be diluted and eventually destroyed. The Scotch Whisky Association, apparently with the aid of the Scottish Executive, eventually brokered a somewhat uneasy settlement announced on 4 December 2003, by which Diageo would continue to use the phrase 'pure malt Cardhu' for its product, but would change the colour of the labelling affixed to it to ensure market differentiation. Meantime the Association would 'urgently' pursue work to provide definitions of a single malt. ${ }^{44}$ But it must be open to question whether leaving this to the Association is good enough; the matter is at least related to the laws of passing off, trade marks and, perhaps, geographical indications and trade descriptions, and it should, as the distillers William Grant \& Sons have argued, be taken up in that legal

\footnotetext{
${ }^{41}$ They can also be of previously unregistered marks already used by a business.

${ }^{42}$ Single malts are produced by an essentially pre-industrial technology, using a watery extract of malted barley dried in peatsmoke and fermented by yeast, with distillation in a pot-still followed by at least three years' storage (preferably much more) in oak (usually sherry) casks.

${ }^{43}$ This is not a 'blended' whisky, blends being typically made by mixing malt whisky with whisky distilled in patent-stills from grains other than malted barley in an industrial mode of production. Nor is it a 'vatted' malt, which a distillery produces by a mixture of its own malts of different ages. See generally David Daiches, Scotch whisky: its past and present (Glasgow: Fontana/Collins, 1980) and R J S McDowall (revised.by William Waugh), The whiskies of Scotland (London: John Murray, 1986).

${ }^{44}$ See the Scotch Whisky Association website, http://www.scotch-whisky.org.uk/, 'Press Releases', 'SWA reaches agreement over Cardhu'. For the background, with illustrations of the offending labels, see http://news.bbc.co.uk/1/hi/scotland/3289181.stm ('Whisky branding deal reached') and accompanying links.
} 
context if the malt whisky industry wishes to have a secure basis for its marketing in future. $^{45}$

A second illustration of the relevance of IP other than patents can be found in the National Cultural Strategy which the Scottish Executive published in 2000, and which was to underpin the development of Scotland's cultural life until 2004 . $^{46}$ Amongst the objectives was the maximisation of the contribution of both the "cultural sector' and the 'creative industries' to Scotland's economy, including the potential for 'cultural tourism'. The Strategy relates to both Scottish culture and culture in Scotland. That this is in turn links to 'smart, successful Scotland' was recognised by the First Minister, Jack McConnell, in a major speech on cultural policy delivered on St Andrew's Day (30 November) 2003:

To create a smart successful Scotland you need the fundamental building block of creativity. The creative industries have shown themselves to be one of the leading growth areas in our economy. And the cultural sector attracts and retains creative people. ${ }^{47}$

The Strategy stated that 'the cultural and creative industries are ... estimated to be worth around $£ 5$ billion [i.e., around 4 per cent of Scottish GDP] to the Scottish economy each year; 50,000 are employed in the cultural sector'. ${ }^{48}$ The creative industries were defined in the Strategy as

the activities which have their origin in individual creativity, skill and talent and which have a potential for wealth and job creation through the generation and exploitation of intellectual property. They comprise Architecture, Advertising, Arts and Cultural Industries, Design (including Fashion, Design and Crafts), Film, Interactive Leisure Software (computer games, consumer packaged software), Music, New Media, Publishing, Radio and Television.

The Strategy suggested that these industries were 'set to grow significantly faster than the economy as a whole', mainly as a result of digitisation of content, opening up not only prospects of rapid, worldwide distribution, but also new applications leading to new cultural forms, new businesses, and inter-activity with users. ${ }^{49}$

\footnotetext{
${ }^{45}$ See http://news.bbc.co.uk/1/hi/scotland/3292103.stm ('Whisky rules should become law').

${ }^{46}$ Creating our future: minding our past, accessible at http://www.scotland.gov.uk/nationalculturalstrategy/docs.

${ }^{47}$ Full text available at http://www.scotland.gov.uk/pages/news/extras/p_00017600.aspx. There are echoes in the passage quoted of the 'Florida thesis', that creativity (defined to include technological, professional and academic as well as artistic and media work) is the decisive source of competitive advantage, and that economic growth occurs most in places open to creativity and attractive to creative people: Richard Florida, The rise of the creative class: and how it's transforming work, leisure, community and everyday life (New York: Basic Books, 2002).

${ }^{48}$ The employment figure rises to 100,000 elsewhere in the document, and also in the Scottish Enterprise website material about the creative industries (see further note 56 below). Compare the GDP percentages with those quoted for the UK, Europe and the USA in Gillian Davies, Copyright and the public interest, 2nd edition (London: Sweet \& Maxwell, 2002), ch. 8.003. For Australia, see Australian Copyright Council and Centre for Copyright Studies, The economic contribution of Australia's copyright industries (2001).

${ }^{49}$ On this theme see also the report of a British Academy working party on the contributions of the Arts, Humanities and Social Sciences (forthcoming January 2004, accessible at http://www.britac.ac.uk/).
} 
Clearly fundamental to all this if it is indeed having, or is to have, the desired economic impact, is the law of copyright, performers' rights, and design rights; perhaps trade marks might also be important as a way of branding and promoting products in a global marketplace. Indeed, without underlying IPR the creative industries might find it very difficult to have any economic life at all. ${ }^{50}$

There has been no sign, however, in subsequent implementation of the Cultural Strategy, or in reporting upon its success or otherwise, that there has been any policy reflection upon relevant parts of IP law in the Executive, or elsewhere. The 2002 Annual Report on the Strategy does report the production of a CD ROM on copyright to guide members of the Scottish Library and Information Council: 'key to its success,' says the Report, 'is the fun element of working through a maze scenario, in learning about copyright information. ${ }^{51}$ However that may be, personal knowledge suggests that few working in the Scottish cultural sector find copyright to be fun; rather, many consider it to present significant difficulties and impediments in achieving their objectives, not least in the context of digital dissemination. ${ }^{52}$

In general the three Annual Reports since the publication of the Strategy simply retail 'good news' stories, such as the establishment of a National Theatre for Scotland, ${ }^{53}$ the introduction of a Gaelic Language Bill, ${ }^{54}$ or the creation of a Scottish Cultural Portal, ${ }^{55}$ but provide no systematic data on the economic contribution of either the cultural sector or the creative industries, or about how they are developing from an economic point of view. Some further information (but not much) can be obtained on the Scottish Enterprise website. ${ }^{56}$ Of course, cultural policy is not simply about the economic, and social welfare factors, such as the environment, the physical and mental health of individuals, personal self-confidence, access and education, are also legitimate and important concerns for government in this area. ${ }^{57}$ But the economic dimension, and along with it the relevant IP issues, seem almost to have been ignored in the implementation and reporting of the Cultural Strategy so far; and that cannot be right. Economists would argue that creative activities that pay off in economic advance arise from product or process innovation, which originates in all sectors of the economy, and it is thus a simple logical error to identify creative

\footnotetext{
${ }^{50}$ See John Howkins, The creative economy: how people make money from ideas (London: Allen Lane The Penguin Press, 2001); Ruth Towse (ed), Copyright in the cultural industries (Cheltenham and Northampton, Mass.: Edward Elgar, 2002).

${ }^{51}$ See http://www.scotland.gov.uk/library5/society/sncs2.pdf, (at 54).

${ }^{52}$ See http://www.law.ed.ac.uk/ahrb/publications/online/chreport1.rtf (registration required), recording a meeting of representatives of the Scottish cultural sector held on 1 September 2002, to discuss copyright issues. Digitisation is important not only in the creative industries but in impressive activities (with associated e-commerce) such as Scottish Cultural Resource Access Network (http://www.scran.ac.uk/), Scottish Archives Network (http://www.scan.org.uk), and Scotland's People (http://www.scotlandspeople.gov.uk/). Universities come into the picture again here, with the development of distance learning packages often disseminated across the Internet.

${ }^{53}$ See http://www.scotland.gov.uk/pages/news/extras/00015600.aspx.

${ }^{54} \mathrm{See}$ http://www.scotland.gov.uk/consultations/culture/glbc-01.asp.

${ }^{55}$ For which see http://www.scotlandsculture.org/index.htm.

${ }^{56} \mathrm{http}: / / \mathrm{www} . \mathrm{scottish}$-enterprise.com/sedotcom_home.htm; click on 'Services to Industry Groups', then on 'Creative Industries'. There seems to be no relevant information on the Scottish Arts Council website (http://www.scottisharts.org.uk/).

${ }^{57}$ See further on this the First Minister's St Andrew's Day speech (cited above, note 47).
} 
industries as a new separate category somehow apart from manufacturing and service industries

Upon what substantive IP issues might the Scottish Executive and Parliament wish to reflect in the further implementation of their economic and cultural strategies? The development of policies seeking the promotion of technology transfer in and from universities is not confined to Scotland, and has prompted discussion elsewhere about IPRs in this context. So for example a committee chaired by Bill Cornish reported for the National Academies Policy Advisory Group (NAPAG) on Intellectual property and the academic community in $1995,{ }^{58}$ and their work was the basis for a Royal Society working group report, Keeping science open: the effects of intellectual property policy on the conduct of science, published in April 2003. ${ }^{59}$ At least some of the issues raised in these documents also have importance beyond the universities, technology and commercialisation. Moreover there is a constant stream of other relevant reports and legislative proposals, mainly at a European level, and there is a clear need, against the background just sketched, for input and response to these from a Scots perspective.

Ownership of IP, highlighted in the Lambert Review, is addressed in both the NAPAG and the Royal Society reports. In relation to the products of university research, what is the scope of the rights of employers under present legislation to both patents and copyrights arising from the work of employees in the course of their employment? ${ }^{60}$ Should these rights be extended to cover the work of students in the universities, which is often a key contribution in the science and technology areas in particular? Can anything be done with the rules on joint ownership of $\mathrm{IP}^{61}$ to help to resolve the difficulties often arising from collaborative research between universities and industry? Should the funders of research be given a stake in resultant IP? Is the entitlement to 'just compensation' from an employer to an employee who has made a patented invention which is of 'outstanding benefit' to the employer ${ }^{62}$ providing an incentive to innovate, and, if so, might it be extended or adjusted to fit other contexts?

Again, what IPRs should be recognised? Will it be for the general good if computer software as such becomes patentable, and what should then be done with the existing copyright protection of the same subject-matter? ${ }^{63}$ Would it be helpful to universities or small businesses in Scotland if technological developments of lesser

\footnotetext{
${ }^{58}$ Henceforth 'NAPAG Report'; accessible at http://www.royalsoc.ac.uk/policy/ (click on '1995').

${ }^{59}$ Henceforth Keeping science open; also accessible at http://www.royalsoc.ac.uk/policy/ (click on '2003').

${ }^{60}$ Patents Act 1977 (henceforth 'PA'), s. 39; Copyright, Designs and Patents Act 1988 (henceforth 'CDPA'), s. 11(2); see NAPAG Report, paras. 12.1-12.3; Keeping science open, paras. 2.8, 4.12. ${ }^{61}$ PA, ss. 7, 36; CDPA, s. 10.

${ }^{62}$ PA, ss. 40, 41. The UK Patent Office Consultation on a Proposed Patents Act (Amendment) Bill considered the present position in this area (see http://www.patent.gov.uk/about/consultations/patact/proposals2.htm, paras. 73-82), but no change is currently proposed (http://www.patent.gov.uk/about/consultations/responses/patact/enforcement.htm, paras. 94-111). See also Keeping science open, para. 3.47.

${ }^{63}$ See W R Cornish, "Cumulation and convergence of intellectual property rights", in P Mirfield and R Smith (eds), Essays for Colin Tapper (London: LexisNexis, 2003), 200-201; Cornish and Llewelyn (above, note 1), ch. 19.26-19.33. A proposal for a Directive on the patentability of computerimplemented inventions was forwarded to the Commission and the Council by the European Parliament in September 2003: see http://www.patent.gov.uk/about/ippd/issues/softpat.htm for the best overview (with relevant links) of current developments.
} 
inventiveness than needed for patents could be registered for a 'second-tier' level of protection without prior examination for validity? ${ }^{64}$ Or should there rather be concentration upon making the process of obtaining a patent generally quicker and easier, without relaxing standards of examination for validity? Shifting away from technology to culture, have recent developments of performers' rights achieved a just and efficient level of protection, or created barriers to the production and dissemination of works embodying these performances? ${ }^{65}$

Both the NAPAG and the Royal Society reports reflect a widespread perception within the universities that IPRs can be a brake upon research and publication of its results. ${ }^{66}$ With regard to patents, should a grace period be introduced, to stop disclosure and publication of results automatically preventing the subsequent grant of a patent? ${ }^{67}$ Under both patents and copyright, how far does the prevention of 'commercial' research in relation to protected material inhibit other researchers building upon that material for the public good ${ }^{68}$ Does the strong protection of databases against unauthorised extraction and reutilisation cause such difficulties for researchers as to outweigh the need to ensure some return to those who invest in the creation of such databases? ${ }^{69}$ Should copyright owners be able also to protect their products with such digital fences as to preclude others from exercising their fair dealing rights, or to limit or exclude those rights by contract? ${ }^{70}$

Enforcement of IP is also an important issue which has recently attracted a European legislative initiative. ${ }^{71}$ In Scotland, legal practitioners specialising in the field sense an increase in local IP litigation which some attribute to the greater willingness of the Scottish judges, compared with their English brethren, to enforce IPRs. Also relevant may be the lower expense of litigation in Edinburgh by comparison with London, the emphasis on written pleadings bringing out the true

\footnotetext{
${ }^{64}$ See NAPAG Report, paras. 6.3-6.5; also W R Cornish, "Scientific research and intellectual property", in (1994) 2(3) Hume Papers on Public Policy, at 48-50. For discussions of a possible Directive in this area, see http://europa.eu.int/comm/internal_market/en/indprop/model/index.htm.

${ }^{65}$ A matter of current concern for the World Intellectual Property Organisation in Geneva: see http://www.wipo.org/documents/en/meetings/2003/avp_im/index.htm. For the current UK position see CDPA Part II as amended, most recently by the Copyright and Related Rights Regulations 2003 (SI 2003 No 2498), reg. 7; and, further, Cornish and Llewelyn (above note 1), ch. 13.30-13.40.

${ }^{66}$ And see also the arguments of McSherry and Bok (above, note 20).

${ }^{67}$ See NAPAG Report, paras. 5.1-5.4; Keeping science open, para. 3.39; and further Cornish (above note 64), 50-2. In December 2002 the DTI Intellectual Property Advisory Committee (IPAC) published a position paper on grace periods (hostile), responding to a Patent Office consultation on the subject: see http://www.intellectual-property.gov.uk/ipac/std/observations.htm.

${ }^{68}$ See PA, s. 60(5); CDPA, s. 29 as amended by SI 2003 No 2498, reg. 9. See NAPAG Report, para. 8.1-8.2; Keeping science open, paras. 3.23, 4.19-4.22, 5.5-5.9, 5.21. For further comment see W R Cornish, M Llewelyn and M Adcock, Intellectual property rights (IPRs) and genetics: a study into the impact and management of intellectual property rights within the healthcare sector (Cambridge: Public Health Genetics Unit, July 2003), section 2C2(a). A detailed study of the subject by Trevor Cook for the Intellectual Property Institute, London, should appear in 2004.

${ }^{69}$ See Keeping science open, ch. 5.

${ }^{70}$ Ibid, para. 4.21.

${ }^{71}$ Proposal for a Directive of the European Parliament and of the Council on measures and procedures to ensure the enforcement of Intellectual Property Rights, COM (2003) 46 (01), Commission of the European Communities, January 2003 (text at http://europa.eu.int/eurlex/en/com/pdf/2003/com2003_0046en01.pdf). IPAC published a report on the enforcement of patent rights in November 2003, for which see http://www.intellectual-property.gov.uk/ipac/pdf/enforce.pdf.
} 
issues between the parties at a relatively early stage, and the focused nature of the Scottish equivalents of the Mareva injunction (arrestment on the dependence) and the Anton Piller order (commission and diligence under the Administration of Justice (Scotland) Act 1972). Special Rules of Court for IP cases were introduced in $1994 .^{72}$ But the advantages claimed for IP litigation in Scotland need to be offset by the absence within the IP rules of provision for speedy trials or streamlined procedures comparable with those available, not only in England, but also, very successfully, in the general commercial cause rules of the Court of Session itself. ${ }^{73}$

In conclusion, then, although IP is rightly a subject of public policy discussion in devolved Scotland, that discussion still has much ground to cover. The protagonists of technology transfer and commercialisation need to take on board questions about IP law itself, and how the answers may be related to their policy objectives. Likewise those whose primary concern is the substance of IP law should become more aware of the impact of their debates in the arenas of economic development, basic and applied research, and general public policy. This of course includes cultural policy which, in Scotland at least, has also been too much divorced from economic as well as IP policy. The Scottish Executive and Parliament may need to accept that there are limits on what government can do for economy and culture beyond the provision of basic infrastructure. Inter-disciplinary sensitivity and research, drawing together work on policy, economics, culture and law (as so well exemplified in the work of Bill Cornish himself) is clearly the way forward; and, it may finally be concluded, not just in Scotland, but in the United Kingdom and its other regions as well. ${ }^{74}$

\footnotetext{
${ }^{72}$ SI 1994, No 1443 (S. 69), ch. 55 (as amended).

${ }^{73}$ The small number of 'Copyright Patents actions initiated' in the General Department of the Court of Session as recorded in the Civil Judicial Statistics since 1995 may be explicable because these figures seem not to include trade marks (amongst registered rights), or common law rights such as passing off and breach of confidence, and also because most intellectual property litigation in Scotland involves primarily the remedy of interim interdict (the equivalent of the English interlocutory injunction), which would be initiated in the Petitions rather than the General Department. The Petitions figures in the Civil Judicial Statistics unfortunately cannot be broken down to reveal figures for intellectual property cases.

${ }^{74}$ In addition to the Lambert Review (above note 34), see the DTI's Innovation Report, Competing in the global economy: the innovation challenge (December 2003), accessible at http://www.dti.gov.uk/innovationreport/.
} 